\title{
Stem cell therapies for myocardial infarction in clinical trials: bioengineering and biomaterial aspects
}

\author{
Akon Higuchi ${ }^{1,2,3,4}$, Nien-Ju Ku' ${ }^{1}$, Yeh-Chia Tseng ${ }^{1}$, Chih-Hsien Pan ${ }^{1}$, Hsing-Fen Li ${ }^{1}$, S Suresh Kumar ${ }^{5}$, Qing-Dong Ling ${ }^{6,7}$ \\ Yung Chang ${ }^{4}$, Abdullah A Alarfaj ${ }^{3}$, Murugan A Munusamy ${ }^{3}$, Giovanni Benelli ${ }^{8,9}$ and Kadarkarai Murugan ${ }^{10,11}$
}

Cardiovascular disease remains the leading cause of death and disability in advanced countries. Stem cell transplantation has emerged as a promising therapeutic strategy for acute and chronic ischemic cardiomyopathy. The current status of stem cell therapies for patients with myocardial infarction is discussed from a bioengineering and biomaterial perspective in this review. We describe (a) the current status of clinical trials of human pluripotent stem cells (hPSCs) compared with clinical trials of human adult or fetal stem cells, (b) the gap between fundamental research and application of human stem cells, (c) the use of biomaterials in clinical and pre-clinical studies of stem cells, and finally (d) trends in bioengineering to promote stem cell therapies for patients with myocardial infarction. We explain why the number of clinical trials using hPSCs is so limited compared with clinical trials using human adult and fetal stem cells such as bone marrow-derived stem cells.

Laboratory Investigation (2017) 97, 1167-1179; doi:10.1038/labinvest.2017.100; published online 4 September 2017

\section{INTRODUCTION}

Human pluripotent stem cells (hPSCs), human induced pluripotent stem cells (hiPSCs), and human embryonic stem cells (hESCs) appear to be promising tools to regenerate damaged tissues or organs because of their ability to differentiate into most cells originating from the three embryonic germ layers in our bodies.

Currently, clinical trials of stem cell therapies using hPSCs have only been conducted for four conditions according to the ClinicalTrial.gov database. These conditions are (1) spinal cord injury, (2) diabetes, (3) acute myocardial infarction (AMI), and (4) macular degeneration (namely Stargardt macular dystrophy and age-related macular degeneration). Recently, hPSC-based therapies in clinical trials have been reported. ${ }^{1-5}$ There are some several review articles that describe the current status of therapies using hESCs and hiPSCs. ${ }^{1-5}$ However, these reviews do not discuss the bioengineering aspects of these therapies, such as hPSC culture and differentiation methods, transplantation method, and conditions of hESCs and hiPSCs. In particular, transplantation methods such as cell suspension injection or cell monolayer transplantation with and without biomaterials (scaffold and hydrogels) at sites of injected have not been reviewed. Here, we have described the current status of stem cell therapies using hPSCs for patients with myocardial infarction (MI), focusing on the bioengineering aspects of these therapies. Furthermore, we discuss clinical trials using human fetal or adult stem cells such as human mesenchymal stem cells (hMSCs), which have been developed to treat patients with AMI. Cardiovascular disease remains the leading cause of death and disability in the USA, claiming more lives each year than cancer, diabetes mellitus, HIV, and accidents combined. ${ }^{6}$ Ischemic heart disease is the predominant contributor to cardiovascular morbidity and mortality; one million MIs occur each year in the USA, while five million patients suffer from chronic heart failure. ${ }^{7}$ Death rates have improved dramatically over the last four decades. However, new approaches are urgently needed for those patients who go on to develop ventricular dysfunction. ${ }^{6,8}$ Over the past decade, stem cell transplantation has emerged as a promising

\footnotetext{
'Department of Chemical and Materials Engineering, National Central University, Jhongli, Taoyuan, Taiwan; ${ }^{2}$ Nano Medical Engineering Laboratory, RIKEN, Wako, Saitama, Japan; ${ }^{3}$ Department of Botany and Microbiology, College of Science, King Saud University, Riyadh, Saudi Arabia; ${ }^{4}$ Department of Chemical Engineering, R\&D Center for Membrane Technology, Chung Yuan Christian University, Chungli, Taoyuan, Taiwan; ${ }^{5}$ Department of Medical Microbiology and Parasitology, Universiti Putra Malaysia, Serdang, Selangor, Malaysia; ${ }^{6}$ Cathay Medical Research Institute, Cathay General Hospital, Hsi-Chi City, Taipei, Taiwan; ${ }^{7}$ Graduate Institute of Systems Biology and Bioinformatics, National Central University, Jhongli, Taoyuan, Taiwan; ${ }^{8}$ Department of Agriculture, Food and Environment, University of Pisa, Via del Borghetto, Pisa, Italy; ${ }^{9}$ The BioRobotics Institute, Scuola Superiore Sant'Anna, Pontedera, Pisa, Italy; ${ }^{10}$ Division of Entomology, Department of Zoology, School of Life Sciences, Bharathiar University, Coimbatore, Tamil Nadu, India and ${ }^{11}$ Department of Zoology, Thiruvalluvar University, Vellore, Tamil Nadu, India

Correspondence: Professor A Higuchi, PhD, Department of Chemical and Materials Engineering, National Central University, No. 300, Jhongda RD., Jhongli 32001, Taoyuan, Taiwan or Professor Q-D Ling, PhD, Cathay Medical Research Institute, Cathay General Hospital, No. 32, Ln 160, Jian-Cheng Road, Hsi-Chi City 221, Taipei, Taiwan.

E-mail: higuchi@ncu.edu.tw or qdling@cgh.org.tw

Received 16 June 2017; revised 1 August 2017; accepted 4 August 2017
} 


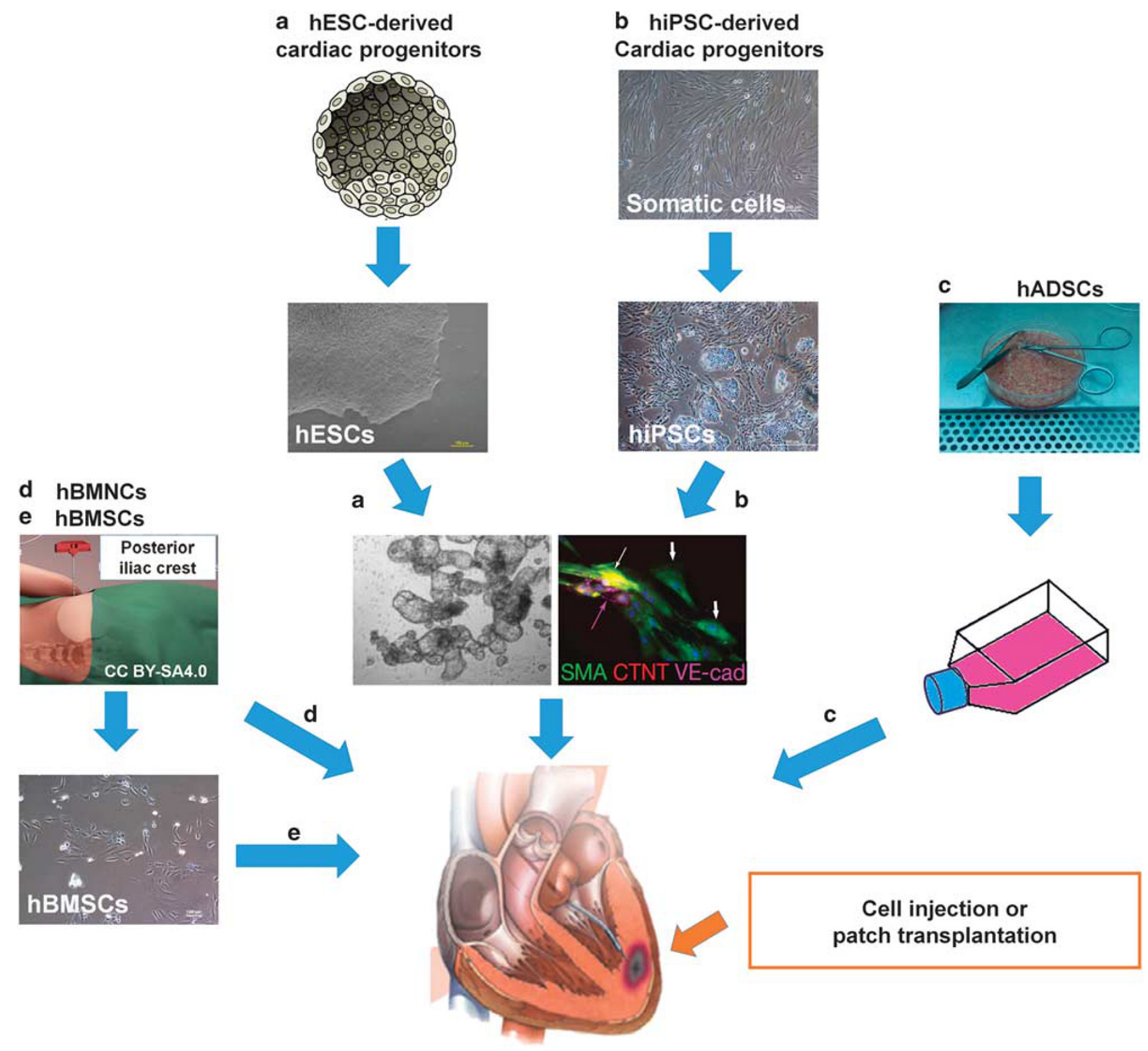

Figure 1 Illustration of stem cell therapy for myocardial infarction disease. (a) hESCs (human embryonic stem cells) were derived from inner cell mass of embryo and differentiated into cardiac progenitors. Cardiac progenitors were intracoronary infused or the patch containing hESC-derived cardiac progenitors was prepared and transplanted into ischemic heart. (b) hiPSCs (human induced pluripotent stem cells) were prepared from transduction or transfection of pluripotent genes or proteins into somatic cells and differentiated into cardiac progenitors. Cardiac progenitors were intracoronary infused or the patch containing hiPSC-derived cardiac progenitors was prepared and transplanted into ischemic heart. (c) hADSCs (human adiposederived stem cells) were isolated from fat tissue and subsequently intracoronary infused. (d) hBMNCs (human bone marrow-derived mononuclear cells) were isolated from bone marrow and subsequently intracoronary infused where bone marrow was isolated from posterior iliac crest. (e) hBMSCs were isolated by cultivation of hBMNCs on TCPS dishes and subsequently intracoronary infused. Parts of Figure adapted, with permission from Nazari et al., ${ }^{4}$ Bartunek et al., ${ }^{42}$ and Yang et al. ${ }^{79}$

therapeutic strategy for acute or chronic ischemic cardiomyopathy. In this review, we have compared the methods and results of clinical trials of therapies for patients with AMI based on hPSCs and hMSCs, including human fetal stem cells (Figure 1).

The goal of this review was (a) to discuss the current status of clinical trials of hPSC-based therapies compared with clinical trials using hMSCs and human fetal stem cells, (b) to discuss the gap between fundamental research and clinical trials using human stem cells, (c) to discuss the use of biomaterials in clinical and pre-clinical studies of hPSCs, hMSCs, and human fetal stem cells, and finally (d) to discuss the bioengineering trends to promote hPSC, hMSC, and human fetal stem cell therapies in regenerative medicine. 


\section{CLINICAL THERAPY FOR MYOCARDIAL INFARCTION USING HESCS}

\section{Fibrin Patch Containing hESCs-Derived Cardiac Progenitors}

hPSCs hold excellent promise for regenerative medicine and drug discovery because of their high capacity to differentiate into many cell types in human tissues. ${ }^{9-11}$ hESC-derived cardiac progenitors have been used for the improvement of the function of infarcted hearts (NCT02057900). In this case, the differentiated cells from hESCs were not directly transplanted into damaged tissue; whereas the cells were directly transplanted into subretinal sites for patients with macular degeneration, ${ }^{12-14}$ a fibrin patch containing hESCderived cardiac progenitors was transplanted into the patient with AMI (Figure 2). ${ }^{15,16}$

Menasche et al. prepared the fibrin patch as follows (Figure 2): ${ }^{15,16}$ (a) hESCs were induced to differentiate into cardiac progenitors on clinical-grade fibroblast feeder layers for 4 days. Of the differentiated cells, $44-64 \%$ expressed stagespecific embryonic antigen (SSEA)-1. (b) The cardiac progenitors were purified using MACS (magnetic-activated cell sorting) targeting SSEA-1-expressing cells. The $95-99 \%$ of cardiac progenitors expressing SSEA-1 surface marker were obtained after purification by MACS. (c) The cardiac progenitors were evaluated for safety, especially the loss of tumor-generating (teratoma formation) capacity. No teratoma formation was observed when 100 times the highest clinical dose of cardiac progenitors was injected into immunodeficient mice. ${ }^{15,16}$ Cytogenetic abnormalities were not observed in the cardiac progenitors. (d) The fibrin patch containing cardiac progenitors was prepared as follows: 10 million cardiac progenitor cells were introduced into $1.1 \mathrm{ml}$ of cell culture medium containing fibrinogen and poured into agarose-coated dishes $(2.5 \mathrm{~cm}$ diameter). Four units of thrombin in $1.1 \mathrm{ml}$ of cell culture medium was added to the agarose-coated dishes containing cardiac progenitors and fibrinogen to generate $25-\mu \mathrm{l}$ droplets. The solution in the agarose-coated dishes was gently agitated to induce gel polymerization. (e) The fibrin patch was applied to the epicardium, followed by covering the patch with a pericardial flap to provide trophic support to the underlying cellular graft (Figure 2).

The efficacy of the fibrin patch containing cardiac progenitors $\left(1-\mathrm{cm}^{2}\right.$ fibrin patch loaded with 700000 cardiac progenitor cells) was assessed echocardiographically in a rat model of MI in a pre-clinical study. The left ventricular (LV) ejection fractions of the rats treated with the fibrin patch with or without cardiac progenitors and without treatment (sham) are shown in Figure $2 .{ }^{15}$ The LV ejection fraction was found to improve after 2 months in the rats treated with the fibrin patch containing cardiac progenitors, in comparison with a normal (reference) LV ejection fraction of approximately $55 \%$ and an abnormal LV ejection fraction of less than $50 \% .{ }^{15}$

\section{Clinical Trial with Fibrin Patch Containing hESCs-Derived Cardiac Progenitors}

In a human clinical trial, a $20-\mathrm{cm}^{2}$ area of autologous pericardium was harvested, and the posterior half was sutured to the epicardium along the borders of the infarct area of a patient with severe ischemic LV dysfunction. This created a pocket between the epicardium and the pericardial flap. ${ }^{16}$ The fibrin patch containing hESC-derived cardiac progenitors was then slipped into the pocket (Figure $2 \mathrm{~b}$ ), and sutures were a

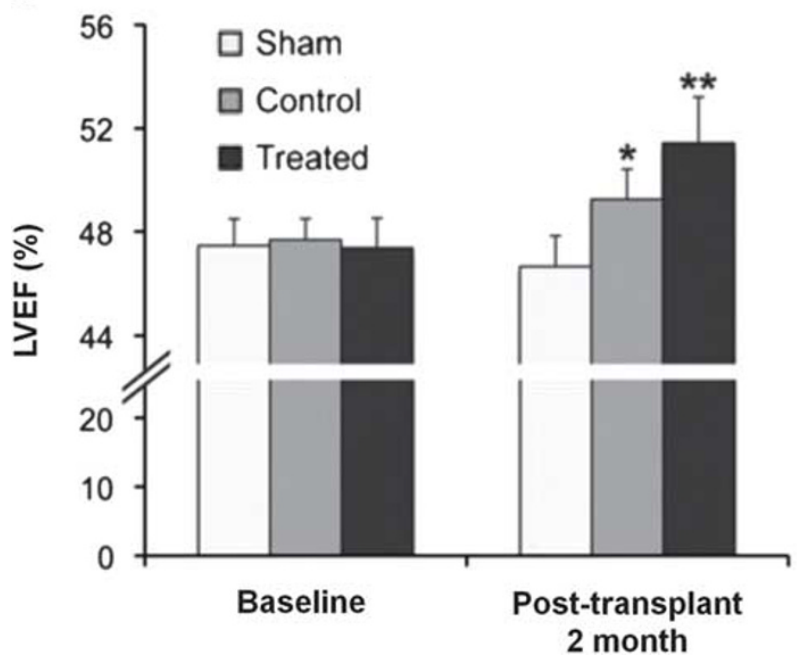

b

Pericardial flap allowing to create the Kangaroo pouch

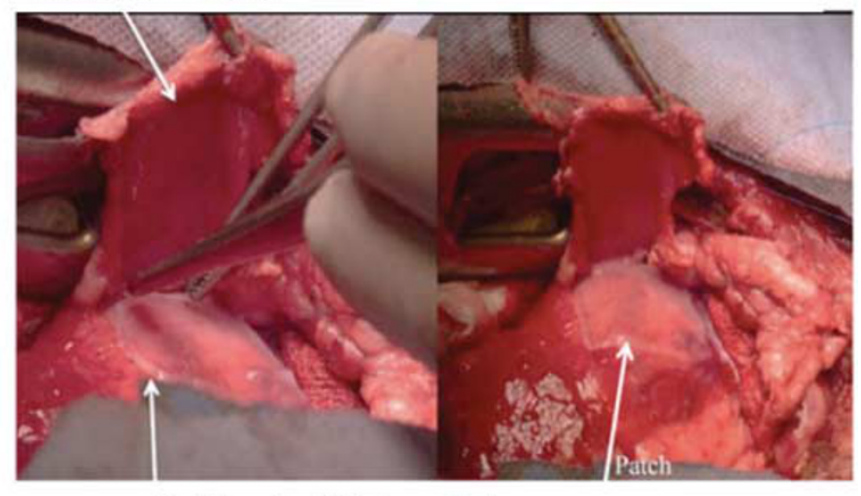

Cell-loaded fibrin patch Overlying the epicardium

Figure 2 Transplantation of a fibrin patch containing human embryonic stem cells (hESC)-derived cardiac progenitors into rat (a) and human (b) of myocardial infarction. (a) Left ventricular ejection fraction (LVEF) change between baseline and 2 months post transplantation. The LVEF of rats treated with the cell-loaded fibrin patch increased relative to that of untreated rats. ${ }^{15}$ Copyright 2015. Adapted with permission from Oxford University Press. (b) Photo of transplantation of the fibrin patch containing hESC-derived cardiac progenitors into the infarcted site of a patient heart, followed by covering the patch with a pericardial flap to introduce trophic factors into the infarcted heart. ${ }^{16}$ Copyright 2015 . Adapted with permission from Oxford University Press. 
used to anchor the anterior half of the pericardial flap to the peri-infarct-affected epicardium, which secured the 'sandwiched' cell-laden patch to the diseased area. Cyclosporine (immunosuppressive drug) as part of an immunosuppressive regime was administered for 2 months. Following transplantation, the patient's serum was found to be negative for Class II antigens, with limited reactivity against non-donor-specific Class I antigens. Three months after the operation, the cardiac functional status of the patient had greatly improved. The patient showed an increased LV ejection fraction (36\% from an initial 26\%), and results of a 6-min walking test showed an increase from 350 to $467 \mathrm{~m}$. The akinetic infarct zone where the fibrin patch containing hESC-derived cardiac progenitors was attached became moderately hypokinetic. ${ }^{16}$

\section{Mechanism of Improved Function by Fibrin Patch}

The mechanism of improved function of infarcted hearts is believed to be based on a paracrine effect. The functional benefits of embryonic stem cell-derived cardiac progenitors are maintained over time, despite rapid loss of the transplanted cells. ${ }^{17}$ The cardiac progenitors secrete several growth factors and extracellular vesicles (EV) in the infarcted hearts, with EVs including exosomes and microparticles that orchestrate paracrine therapeutic effects. In this clinical trial,, 16 mature cardiomyocytes were not used, but cardiac progenitors expressing the SSEA-1 surface marker and the cardiac genes Isl-1 and $M e f 2 c$ were used. The cell source (ie, cardiac progenitors or mature cardiomyocytes) that is more effective in improving infarcted heart function should be a point of discussion. Only $16 \mathrm{hESC}$ lines with various human leukocyte antigen (HLA) types were prepared and immunosuppressive treatment was used in this study. It might be necessary to use more hESCs with different HLA (MHC class I and class II) types to treat diverse recipients of this therapy.

Currently, no other clinical trials using hPSCs have been reported for patients with MI, although there have been several animal studies on hESC-based therapies to improve cardiac function in infarcted animals. ${ }^{18-20}$

\section{CLINICAL THERAPIES FOR MI USING ADULT AND FETAL STEM CELLS \\ MI Therapies Using Adult and Fetal Stem Cells}

AMI is a common cause of disability and death, although several medical approaches, such as coronary artery bypass grafting $(\mathrm{CABG})$ and percutaneous coronary intervention (PCI), have been developed to ameliorate these effects. Myocardial ischemia results in the loss of contractile tissue, which disrupts the mechanical performance of the LV of patients with AMI. ${ }^{21}$ In this case, human adult stem cell (hASC) treatment, which involves (a) inhibition cardiomyocyte apoptosis, (b) growth factor secretion from hASCs, and (c) cardiomyocyte generation and angiogenesis by hASCs, has emerged as a novel alternative therapy to regenerate damaged myocardium. Typically, autologous bone marrow mononuclear cells were administered via intracoronary injection into an MI site 4-8 days after PCI procedures in patients with AMI. Other cell sources, namely autologous or allogenic MSCs from bone marrow, cardiopoietic stem cells, mononuclear cells from peripheral blood, and Wharton's jelly-derived MSCs, have also been used for AMI therapy (Table 1). No trial of human adipose-derived stem cells (hADSCs) for AMI therapy was found in our database research (Table 1).

\section{Therapies Using hBMNCs}

Since Orlic et al. reported the first clinical trial of an intracoronary infusion of autologous human mononuclear cells derived from bone marrow (hBMNCs) for patients with $\mathrm{MI}$ and found improvement of LV function, ${ }^{22}$ a number of clinical trials on hBMNCs and other adult or fetal cell sources for patients with MI have been reported, including ASTAMI, ${ }^{23}$ BOOST, ${ }^{24-26}$ REPAIR-AMI, ${ }^{27-31}$ STEMI, ${ }^{32}$ REGENT, ${ }^{33}$ TAC-HFT, ${ }^{34}$ PROCHYMAL, ${ }^{35}$ SCIPIO, ${ }^{36}$ TIME, ${ }^{37}$ LATE TIME, ${ }^{38}$ HEBE, ${ }^{39}$ BONAMI, ${ }^{40}$ CADUCEUS, ${ }^{41}$ C-CURE, ${ }^{42}$ SCAMI ${ }^{43}$ CHINA-AMI, ${ }^{44}$ REGERATION-AMI, ${ }^{45}$ and other trials ${ }^{22,46-48}$ (Table 1).

A typical treatment is as follows: (1) Patients with a recent MI and left ventricular dysfunction (typically with a left ventricular ejection fraction (LVEF) of $<50 \%$ ) who had undergone successful PCI with stent placement are selected, after approval by the relevant institutional review boards and with informed consent of the patients. (2) Bone marrow (23$128 \mathrm{ml}$, and typically $50 \mathrm{ml}$ ) is aspirated from the posterior iliac crest, and hBMNCs are separated from the bone marrow by density gradient centrifugation, which may be compared with the $400-1000 \mathrm{ml}$ of bone marrow that is aspirated for the treatment of hematopoietic diseases with bone marrow transplantation. (3) hBMNCs (typically $100-300 \times 10^{6}$ cells) are resuspended into a small amount of solution (typically $10 \mathrm{ml}$ ), and an intracoronary infusion of the hBMNC solution is introduced into the MI site of the patient at a few hours to 2 weeks after PCI treatment (typically 3-8 days after PCI). hBMNCs contain $2-4 \%$ hematopoietic stem cells/endothelial progenitor cells and $0.01 \%$ MSCs, and most hBMNCs are composed of hematopoietic mononuclear cells at various stages of maturation. ${ }^{6,49}$

In early trials, such as the BOOST ${ }^{24-27,50}$ and REPAIR-AMI trials, ${ }^{29}$ intracoronary autologous hBMNC transfer improved several parameters of diastolic function in patients with AMI. This improved cardiac function can be explained by the role of $\mathrm{CD}_{3} 4^{+}$hematopoietic stem cells/endothelial progenitor cells in (a) angiogenesis, (b) transdifferentiation into smooth muscle cells, endothelial cells, and cardiomyocytes in vivo, and (c) growth factor secretion. ${ }^{6,51,52}$ However, transplantation of hematopoietic stem cells $\left(\mathrm{CD} 34^{+} \mathrm{CD} 133^{+}\right.$cells) was found to improve LVEF only minimally $(1.8 \%)$, whereas hBMNC transplantation led to excellent improvement of LVEF $(4.41 \%){ }^{53}$ 
Table 1 Clinical trial results of stem cell transplantation (intracoronary transfer) on patients with acute myocardial infarction, which have been reported in references

\begin{tabular}{|c|c|c|c|c|c|c|c|c|c|c|}
\hline $\begin{array}{l}\text { Clinical trial } \\
\text { name }\end{array}$ & Cell type & Cell no. (BM volume) & $\begin{array}{l}\text { Time for } \\
\text { injection }\end{array}$ & $\begin{array}{c}\text { Patient no. } \\
\text { (control/cell } \\
\text { transfer) }\end{array}$ & $\begin{array}{l}\text { LVEF baseline } \\
\text { (control/cell } \\
\text { transfer) }\end{array}$ & $\begin{array}{l}\text { LVEF increase (\%) } \\
\text { (control) }\end{array}$ & $\begin{array}{l}\text { LVEF increase (\%) } \\
\text { (cell transfer) }\end{array}$ & Overall effectiveness & $\begin{array}{l}\text { Clinical trial } \\
\text { number }\end{array}$ & Ref (year) \\
\hline \multirow[t]{2}{*}{ BOOST } & Autologous BMNCs & $25 \times 10^{8}$ cells & 4.8 days after & $30 / 30$ & $51.3 \% / 50.0 \%$ & $0.7 \%$ after & $6.7 \%$ after & LVEF increased in BMNC & NCT00224536 & $24(2004)$ \\
\hline & & (128 ml BM) & $\mathrm{PCl}$ & & & 6 months & 6 months & group & & \\
\hline ASTAMI & Autologous BMNCs & (50 ml BM) & $5-8$ days & $25 / 24$ & No data available & No data available & No data available & Not specified & NCT00199823 & $23(2005)$ \\
\hline & Autologous BMNCs & $68 \times 10^{6}$ cells & 6 days after & $50 / 50$ & $41.9 \% / 41.9 \%$ & $7.6 \%$ after & $7.6 \%$ after & No effect on BMNC & NCT00199823 & $46(2006)$ \\
\hline & & (50 ml BM) & AMI & & & 6 months & 6 months & transplantation & & \\
\hline \multirow[t]{2}{*}{ (REPAIR-AMI) } & Autologous BMNCs & $236 \times 10^{6}(50 \mathrm{ml} \mathrm{BM})$ & $3-6$ days after & $103 / 101$ & $46.9 \% / 48.3 \%$ & $3.0 \%$ after & 5.5\% After & Contractile function & NCT00279175 & $27(2006)$ \\
\hline & & & $\mathrm{PCl}$ & & & 4 months & 4 months & improvement in BMNC group & & \\
\hline \multirow[t]{2}{*}{ REPAIR-AMI } & Autologous BMNCs & Unknown & $3-6$ days after & $103 / 101$ & No data available & No data available & No data available & Effective & NCT00279175 & $28(2006)$ \\
\hline & & & $\mathrm{PCl}$ & & & & & & & \\
\hline \multirow[t]{2}{*}{ BOOST } & Autologous BMNCs & $25 \times 10^{8}$ cells & 4.8 days after & $22 / 20$ & $51.3 \% / 50.0 \%$ & $3.1 \%$ after & $5.9 \%$ after & No statistical difference & NCT00224536 & $25(2006)$ \\
\hline & & (128 ml BM) & $\mathrm{PCl}$ & & & 18 months & 18 months & after 18 months & & \\
\hline \multirow[t]{2}{*}{ STEMI } & Autologus BMNCs & $304 \times 10^{6}$ cells & 1 day after $\mathrm{PCl}$ & $34 / 33$ & $46.9 \% / 49.1 \%$ & $2.6 \%$ after & $2.7 \%$ after & Significant reduction of Ml & NCT00264316 & $32(2006)$ \\
\hline & & (130 ml BM) & & & & 4 months & 4 months & size in BMNC group & & \\
\hline \multirow[t]{2}{*}{ REPAIR-AMI } & Autologous BMNCs & (50 ml BM) & 3-6 days after & $28 / 30$ & $45.6 \% / 47.8 \%$ by & Not analyzed & N.A. after & Improvement in maximal & NCT00279175 & $29(2007)$ \\
\hline & & & $\mathrm{PCl}$ & & Doppler study & & 4 months & vascular conductance capacity & & \\
\hline \multirow[t]{3}{*}{ BOOST } & Autologous BMNCs & $25 \times 10^{8}$ cells & 4.8 days after & $30 / 30$ & $51.3 \% / 50.0 \%$ & $-3.2 \%$ after & $-2.5 \%$ after & No improvement of LVEF by & NCT00224536 & $26(2009)$ \\
\hline & & (128 ml BM) & $\mathrm{PCl}$ & & & 61 months & 61 months & single dose BMNCs & & \\
\hline & & & & & & & & transplantation & & \\
\hline \multirow[t]{3}{*}{ REGENT } & Autologus BMNCs & $1.8 \times 10^{8}$ for BMNCs, & 3-12 days after & $40 / 160$ & & $0 \%$ after & $3 \%$ after 6 months & No significant difference & NCT00316381 & 33 (2009) \\
\hline & or CD34-CXCR cells & $1.9 \times 10^{6}$ cells for & AMI & & & 6 months & & between cell-treated group and & & \\
\hline & & CD34-CXCR cells & & & & & & placebo group & & \\
\hline \multirow[t]{2}{*}{ REPAIR-AMI } & Autologous BMNCs & $50 \mathrm{ml} \mathrm{BM}$ & $3-6$ days after & $28 / 30$ & $40.1 \% / 38.8 \%$ & $-0.4 \%$ after & $7.7 \%$ after & Effective if $E F<48.9 \%$ on & NCT00279175 & $30(2009)$ \\
\hline & & & AMl & & & 12 months & 12 months & basekine & & \\
\hline \multirow[t]{2}{*}{ PROCYMAL } & Allogeneic BMSCs & $0.5,1.6$, and & 3-10 days after & $21 / 39$ & $45.1 \% / 47.3 \%$ & $5.2 \%$ after & $1.8 \%$ after & hMSC treatment, but not & NCT00114452 & $35(2009)$ \\
\hline & & 5 million/kG & AMI & & & 12 months & 12 months & placebo, increased LVEF. & & \\
\hline \multirow[t]{3}{*}{ REPAIR-AMI } & Autologus BMNCs & (50 ml BM) & $3-6$ days after & $101 / 100$ & $48.7 \% / 45.4 \%$ & $-1.8 \%$ after 2 & $4.7 \%$ after 2 year & Infarct size and regional & NCT00279175 & $31(2010)$ \\
\hline & & & AMl & & & year & & contractility were improved & & \\
\hline & & & & & & & & in BMNC treated group. & & \\
\hline \multirow[t]{2}{*}{ TAC-HFT } & Autologus BMSCs & $200 \times 10^{6}$ cells & Unknown & $20 / 40$ & No data available & No data available & No data available & No data available & NCT00768066 & $34(2011)$ \\
\hline & or BMNCs & & & & & & & & & \\
\hline
\end{tabular}

$\mathrm{BM}$, bone marrow; BMNCs, bone marrow-derived mononuclear cells; BMSCs, bone marro-derived mesenchymal stem cells; CABG, coronary artery bypass grafting; CD34-CXCR, CD34+CXCR4+ bone marrow

cells; CDCs, cardiosphere-derived cells; CSCs, c-kit-positive cardiac stem cells; EBT, endomyocardial biopsy tissue; PNMCs, pheripheral blood mononuclear cells; PBLs, periphera blood leucocytes; PCl, percutaneous coronary intervention; WJ-MSCs, Wharton's jelly-derived mesenchymal stem cells. 
Granulocyte colony-stimulating factor (G-CSF) is known to mobilize hematopoietic stem cells from bone marrow to peripheral blood. Therefore, several trials on the treatment of patients with AMI using G-CSF instead of intracoronary transfusion of hBMNCs were performed to determine whether hematopoietic stem cells in hBMNCs have a major role in improvements in patients with AMI. However, G-CSF treatment showed almost no effect in patients with AMI in several clinical trials. ${ }^{51,54,55}$

The timing of infusion of the intracoronary hBMNCs following PCI in patients with AMI seems to be important. Early infusion of hBMNCs (less than $24 \mathrm{~h}$, REGENERATEAMI trial ${ }^{45}$ ) or late infusion (2-3 weeks after AMI, Late TIME trial $^{38}$ ) was not shown to improve global or regional function when the patients were evaluated at 6-12 months after AMI. Infusion of intracoronary hBMNCs at 4-7 days after PCI or AMI seems to be the best interval for improvements in LVEF, LV end-systolic dimension, and incidence of revascularization with this treatment. ${ }^{56}$ However, Traverse et al. reported that patients with AMI who underwent infusion of intracoronary hBMNCs following PCI at 3 or 7 days after PCI showed recovery of regional and global LV function similar to patients in the placebo group (Time trial), and no effect of infusion of intracoronary hBMNCs in patients with AMI was reported in this trial. ${ }^{37}$

Dill et al. ${ }^{30}$ reported that the intracoronary administration of hBMNCs in AMI patients improved LVEF and entirely abrogated progressive end-systolic volume (ESV) expansion.

Although numerous experimental and clinical trials $^{24-27,29,31,32,40,50,57}$ and meta-analyses ${ }^{53,56}$ have demonstrated the benefits of hBMNCs on myocardial ischemia, the mechanisms by which multiple cells derived from the bone marrow function in cardiac repair remain unclear, and some reports have indicated that the intracoronary infusion of hBMNCs did not enhance cardiac function. ${ }^{32,46,58}$ In summary, intracoronary transfusion of hBMNCs in patients with AMI seems to induce a small increase in LVEF and have a limited impact on left ventricular remodeling. However, infarct size is typically decreased by hBMNC transplantation. ${ }^{24-27,29,31,32,40,50,57}$

Several other sources of cells have been used to treat patients with AMI. Hirsch et al. performed a randomized controlled trial to investigate the effects of intracoronary infusion of mononuclear cells from peripheral blood and bone marrow in patients with AMI. ${ }^{39}$ The patients treated with PCI received an intracoronary infusion of mononuclear peripheral blood cells (66 patients) or hBMNCs (69 patients) at 3-8 days after AMI. The standard therapy (no infusion of mononuclear cells) was also included in this HEBE trial. Global and regional LV volumes and myocardial function were evaluated by magnetic resonance imaging (MRI) before randomization and 4 months following treatment. ${ }^{39}$ There found no significant difference in infarct size or LVEF in these three groups.

\section{Therapies Using CD $34^{+}$CXCR4 ${ }^{+}$Progenitor Cells}

hBMNCs contain heterogeneous populations of cells, consisting of committed monocyte, lymphocyte, and granulocyte lineages, as well as subpopulations of progenitor cells and multipotent stem cells. These cells are all expected to have important roles in functional and structural recovery of the myocardium. However, the effect of intracoronary infusion of hBMNCs is still unclear after several clinical trials. Therefore, Tendera et al. conducted a clinical trial (REGENT) using specific populations of hBMNCs to investigate whether specific types of cells could improve the recovery of patients with AMI. ${ }^{33}$ They selected CD34 and CXCR4 (chemokine receptor type 4$)$-expressing cells $\left(\mathrm{CD} 34^{+} \mathrm{CXCR} 4^{+}\right.$progenitor cells) using MACS after isolation of hBMNCs, because CXCR4 binds to stromal cell-derived factor 1 (SDF-1) in the myocardium. Since patients with AMI show upregulated SDF-1 expression in the ischemic myocardium, CXCR4 ${ }^{+}$ cells are expected to mobilize, home, and engraft to the ischemic myocardium. ${ }^{59}$ In contrast, CD34 ${ }^{+}$cells are known to be hematopoietic/endothelial progenitor cells. Two million $\mathrm{CD}_{3} 4^{+} \mathrm{CXCR}^{+}$progenitor cells were introduced in an intracoronary infusion into patients 7 days after PCI. They evaluated the cardiac function in three groups of patients: (a) an unselected hBMNC-treated group (80 patients), a CD34 ${ }^{+}$ $\mathrm{CXCR}^{+}$progenitor cell-treated group (80 patients), and a control group that did not receive cell therapy (40 patients). ${ }^{33}$

LVEF increased by $3 \%$ in patients treated with hBMNCs and $\mathrm{CD} 34^{+} \mathrm{CXCR} 4^{+}$progenitor cells, whereas no change in LVEF was observed in patients in the control group after 6 months. A significant increase in LVEF was only found in patients treated with $\mathrm{hBMNCs}$ or $\mathrm{CD} 34^{+} \mathrm{CXCR} 4^{+}$progenitor cells who had an LVEF of $<37 \%$ before cell treatment. ${ }^{33}$ There was no clinical difference between hBMNC-treated group and the $\mathrm{CD} 34^{+} \mathrm{CXCR} 4^{+}$progenitor cell-treated group in this study. However, the hBMNC-treated group had only $50-70 \mathrm{ml}$ of bone marrow harvested, whereas the CD $34^{+}$ $\mathrm{CXCR}^{+}$progenitor cell-treated group had $100-120 \mathrm{ml}$ of bone marrow harvested in this study. ${ }^{33}$ These results, along with the laborious isolation of specific cells using MACS, suggests that $\mathrm{CD} 34^{+} \mathrm{CXCR} 4^{+}$cell treatment is not preferable to conventional hBMNC treatment.

\section{Therapies Using Autologous and Allogeneic hMSCs}

Autologous bone marrow-derived hMSCs were also used to treat patients with AMI. Lee et al. performed a randomized pilot clinical trial to investigate the safety and efficacy of autologous hMSCs in patients with AMI. ${ }^{47}$ Autologous hMSCs were derived as follows: Twenty-five microliter of bone marrow was aspirated from each patient. hBMNCs were prepared from bone marrow by the density gradient centrifugation method using Histopaque-1077. hBMNCs were cultured on tissue culture polystyrene (TCPS) dishes to remove non-adherent cells and expanded for 4-5 passages; most of the cells remaining in the TCPS dishes were hMSCs. The patients treated with autologous hMSCs showed an LVEF 
improvement of $5.9 \%$, whereas patients in the control group showed only a $1.6 \%$ improvement in LVEF, which was determined by single-photon emission computed tomography (SPECT) 6 months after treatment. ${ }^{47}$ Therefore, this study suggests that intracoronary infusion of bone marrowderived hMSCs is safe, with modest improvements in LVEF at a 6-month follow-up visit.

Allogeneic but not autologous bone marrow-derived hMSCs were also used to treat patients with AMI. Hare et al. performed a double-blind, placebo-controlled, doseranging $(0.5,1.6$, and 5 million cells $/ \mathrm{kg})$ safety trial (PROCYMAL) of intravenous allogeneic bone marrowderived hMSCs in reperfused patients with AMI, where hMSCs were transplanted on days 1-10 after AMI (Supplementary Figure 1A). ${ }^{35}$ The patients treated with hMSCs showed less PVC (premature ventricular contraction) compared with that of patients in the placebo control group on day 10 following hMSC transplantation (Supplementary Figure 1B). Furthermore, patients treated with hMSC showed increased LVEF and reverse remodeling of the heart (Supplementary Figure 1C), whereas patients in the placebo group did not show any improvement in cardiac function based on cardiac magnetic resonance imaging. Furthermore, pulmonary function evaluation showed an improvement in forced expiratory volume in $1 \mathrm{~s}$, and ambulatory electrocardiogram monitoring indicated a reduction in ventricular tachycardia episodes in hMSC-treated patients. ${ }^{47}$ This study demonstrated the relatively good therapeutic effect of allogenic hMSCs in patients with AMI, as well as the safety of this treatment.

\section{Therapies Using Autologous Cardiac Stem Cells and Cardiosphere-Derived Cells}

Autologous cardiac stem cells from bone marrow were also used to treat patients with chronic heart disease. In the C-CURE multicenter randomized trial, autologous bone marrow-derived cardiopoietic stem cells were infused into patients endoventricularly. ${ }^{42}$ The cardiopoietic stem cells were prepared as follows: hBMNCs were derived from bone marrow using the conventional centrifugation method. Then, hBMNCs were cultured on TCPS dishes for one passage and subsequently cultured in a medium containing a cardiogeneic cocktail (transforming growth factor- $\beta$ [TGF- $\beta]$, bone morphogenetic protein 4 [BMP 4], activin A, fibroblast growth factor 2 [FGF 2], cardiotrophin, and $\alpha$-thrombin) for three passages. Of the differentiated cells, a minimum of $85 \%$ of cells showed a more than 2-fold induction of MEF2c (myocyte enhancer factor 2C), which is the gene involved in cardiac morphogenesis, in the nucleus versus the cytosol. ${ }^{42}$ The cardiopoietic stem cells were injected into mapped area at 1 min per injection, with an average of 18 injections per patient (brown spots in Figure 3), with the cells delivered into an area of dysfunctional but viable myocardium characterized by a voltage of $>4 \mathrm{mV}$ (green-colored region in the unipolar map in Figure 3a) with reduced LLS (red color areas in Figure $3 \mathrm{~b}) .42$

In this study, LVEF improved from 27.5 to $34.5 \%$ with infusion of autologous cardiopoietic stem cells, whereas patients that were not treated with the cells showed no improvement in LVEF. ${ }^{42}$ The reduction in LV end-systolic volume was also found to be significant in the group treated with autologous cardiac stem cells compared with the group of patients that were not treated with cardiopoietic stem cells. This demonstrated that cardiopoietic stem cell therapy is feasible and safe, with signs of benefit for patients with chronic heart failure.

Makkar et al. used cardiosphere-derived cells (CDCs) for the treatment of patients 2-4 weeks after MI (CADUCEUS clinical trial). ${ }^{41}$ CDCs were prepared as follows (Figure 4): $\sim 275 \mathrm{mg}$ of endomyocardial tissue was obtained by biopsy. The tissue sample was minced into about 1-mm explants, and the explants were cultured on TCPS dishes. This process was similar to the general method for preparing hADSCs from fat tissue samples. ${ }^{60,61}$ The adhered cells were harvested and subsequently cultured in suspension to generate threedimensional (3D) cardiospheres. Then, the cardiospheres were cultured on TCPS dishes to generate CDCs (41). CDCs were cultured for $2-5$ passages to obtain the expected dose of CDCs within 36 days. Of the CDCs, 95\% expressed CD105 $\left(\mathrm{CD} 105^{+}\right)$, whereas $\mathrm{CD} 45^{+}$cells were $<5 \%$ of CDCs. Autologous CDCs (12.5 million or 25 million) were administered an intracoronary infusion into the infarct-related artery of the patients 1.5-3 months after MI in patients showing a 39\% mean LVEF and $24 \%$ scar in their hearts. No major adverse cardiac events occurred in patients in the control group or CDC infusion group. ${ }^{41}$ Furthermore, no cardiac tumors developed and no patients died in either group, suggesting that CDC infusion is safe. Cardiac scar tissue was significantly reduced and new healthy tissue was generated after treatment with CDCs in this clinical trial (CADUCEUS) (Figure 5). ${ }^{41}$ However, this trial did not show an improvement in LVEF, end-diastolic volume, or endo-systolic volume with CDC infusion relative to that in the control group. This is probably because of the relatively small numbers of cells infused and extremely low survival rate of transfused cells in vivo. There is the possibility that CDC infusion of injectable hydrogels into the infarct-related artery of the patients could lead to improved cardiac function after treatment.

Autologous cardiac stem cells (CSCs, c-kit ${ }^{+}$, lineagenegative cells) were also used to treat patients with ischemic cardiomyopathy (SCIPIO clinical trial). ${ }^{36}$ CSCs were prepared as follows: The right atrial appendage was harvested during coronary artery bypass grafting. CSCs were also isolated using a method similar to that of purifying hADSCs from fat tissues. ${ }^{61}$ Briefly, the atrial tissues were cut into small pieces $\left(<1 \mathrm{~mm}^{3}\right)$ and suspended in medium. After collagenase digestion of the tissues, the cells were plated on TCPS dishes and cultured for several passages to isolate CSCs. Typically, only stem cells can adhere and expand on TCPS dishes. 
a
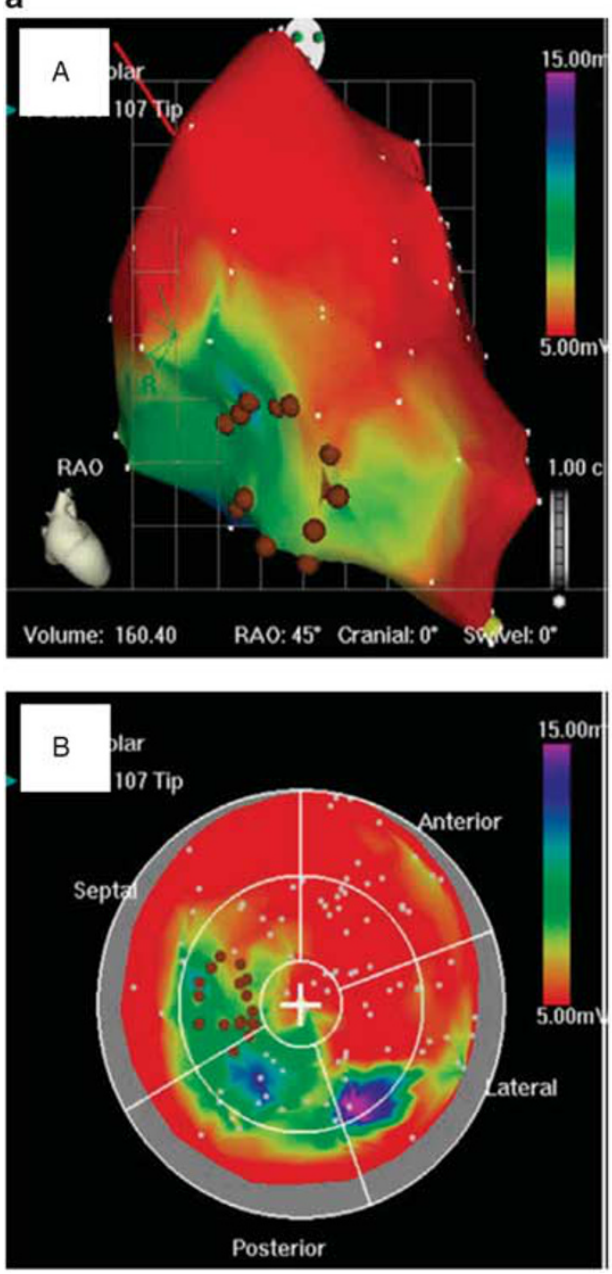

b
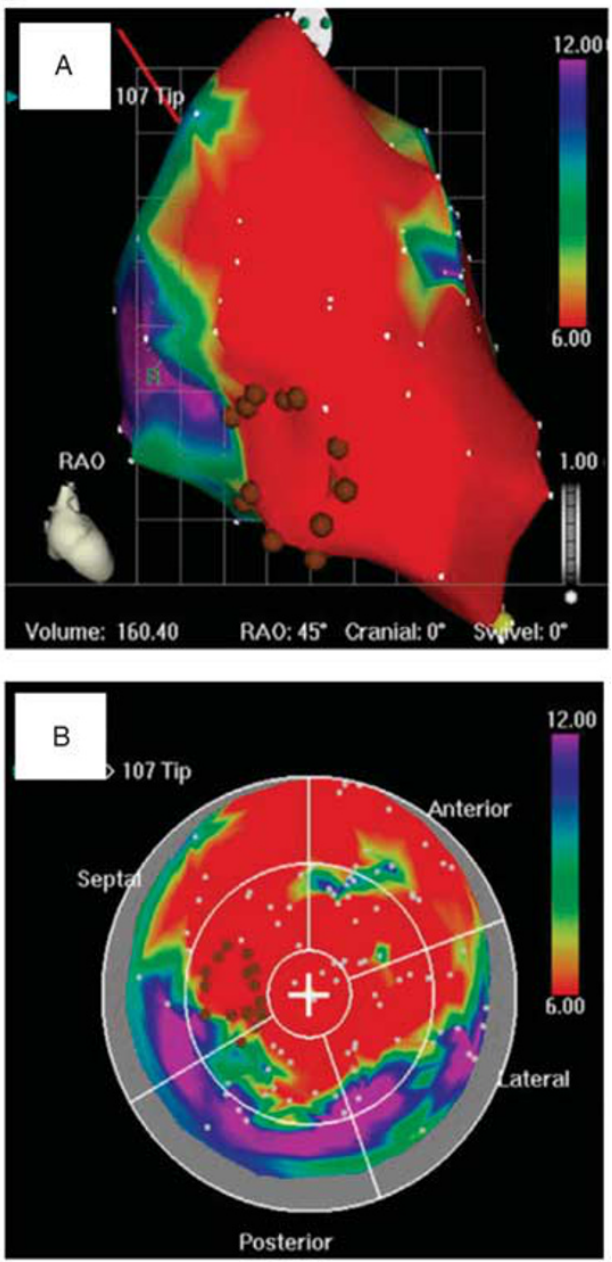

Figure 3 Stem cell delivery assessed by intramyocardial mapping and navigation. (a,b) Endomyocardial delivery of bone marrow-derived cardiopoietic stem cells using electromechanical guidance in a patient enrolled in the C-CURE trial. The upper color-coded illustrations show a right anterior oblique projection of unipolar voltage $(\mathbf{a}(\mathrm{A}))$ and linear local shortening maps (LLS, $\mathbf{b}(\mathrm{A})$ ). A bulls-eye view of electrical and mechanical maps with unipolar voltage $(\mathbf{a}(\mathrm{B}))$ and linear local shortening $(\mathbf{b}(\mathrm{B}))$. Stem cells were transplanted (brown spots) into areas of dysfunctional yet viable myocardium characterized by a voltage of $>4 \mathrm{mV}$ (green color on the unipolar map) with reduced LLS (red color on the LLS map). ${ }^{42}$ Copyright 2013 . Adapted with permission from the American College of Cardiology Foundation.

Subsequently, the cells were sorted by MACS, which targets c-kit-expressing cells (c-kit ${ }^{+}$cells). One million CSCs were infused into anterior wall infarcts, and 0.5 million cells were infused into infarcts in the left circumflex or right coronary artery. ${ }^{36}$

From $30.3 \%$ before CSC infusion, LVEFs recovered to $38.5 \%$ at 4 months after infusion of CSCs, whereas the LVEFs of patients in the control group did not change $(30.1 \%)$ at 4 months after coronary artery bypass grafting. ${ }^{36}$ This study suggests that intracoronary infusion of autologous CSCs is a promising approach to decrease infarct size and increase recovery of LV systolic function after MI. However, the effect of transplantation of CSCs $\left(\mathrm{c}-\mathrm{kit}^{+} \text {cells }\right)^{36}$ as well as cardiosphere-derived cells ${ }^{41}$ on the treatment of the patients with myocardial infarction is currently considered to be controversial. The effect of transplantation of c-kit ${ }^{+}$cardiac stem cells is generally considered to be due to a paracrine effect of c-kit ${ }^{+}$cardiac stem cells. ${ }^{62,63}$ Furthermore, it should be noted that from a bioengineering point of view, the isolation and collection of CSCs is difficult compared with the isolation and collection of stem cells derived from bone marrow or adipose tissue. It is necessary to develop much sophisticated methods to isolate CSCs, cardiopoietic stem cells, and CDCs from tissues in future.

\section{Therapies Using Fetal Stem Cells}

Human Wharton's jelly-derived mesenchymal stem cells (hWJ-MSCs) were purified from a continuum from the sub-amnion to the perivascular region of umbilical cords. ${ }^{64,65}$ hWJ-MSCs express some typical markers of hESCs and hMSC in early passages. ${ }^{65}$ Furthermore, hWJ-MSCs can be induced to differentiate into endothelial cells and cardiomyocytes. ${ }^{66-68}$ 
a

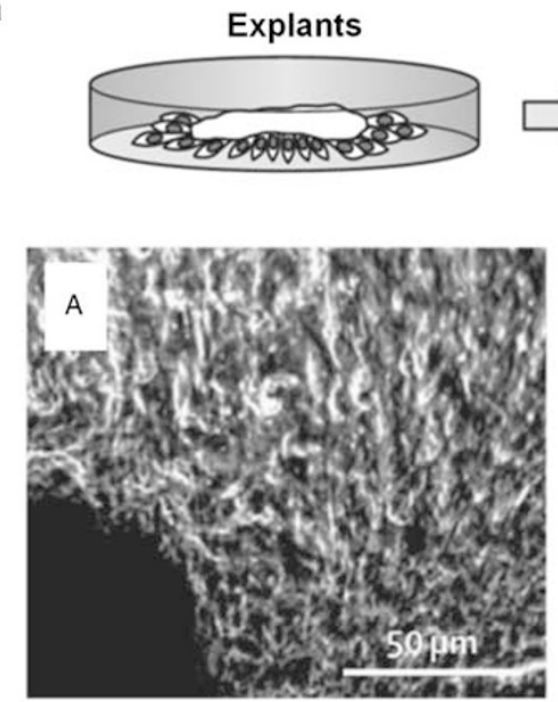

b

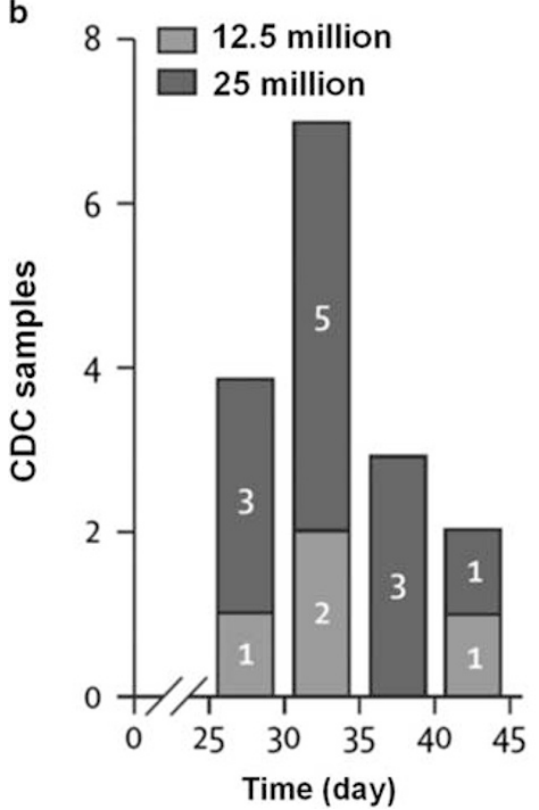

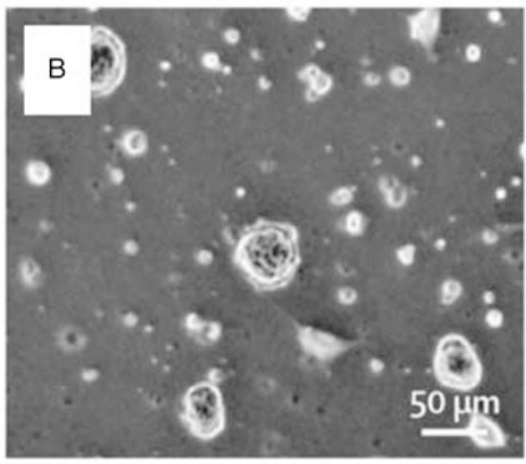

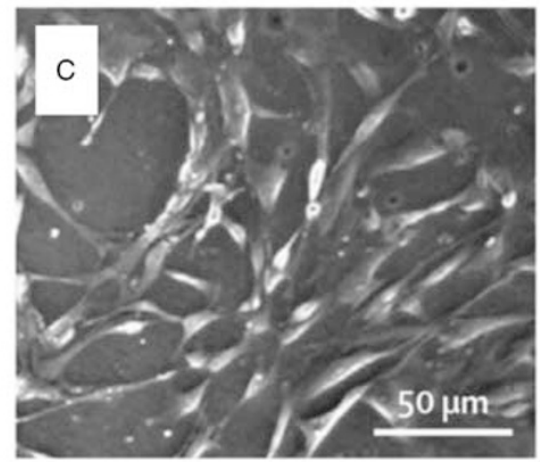

C
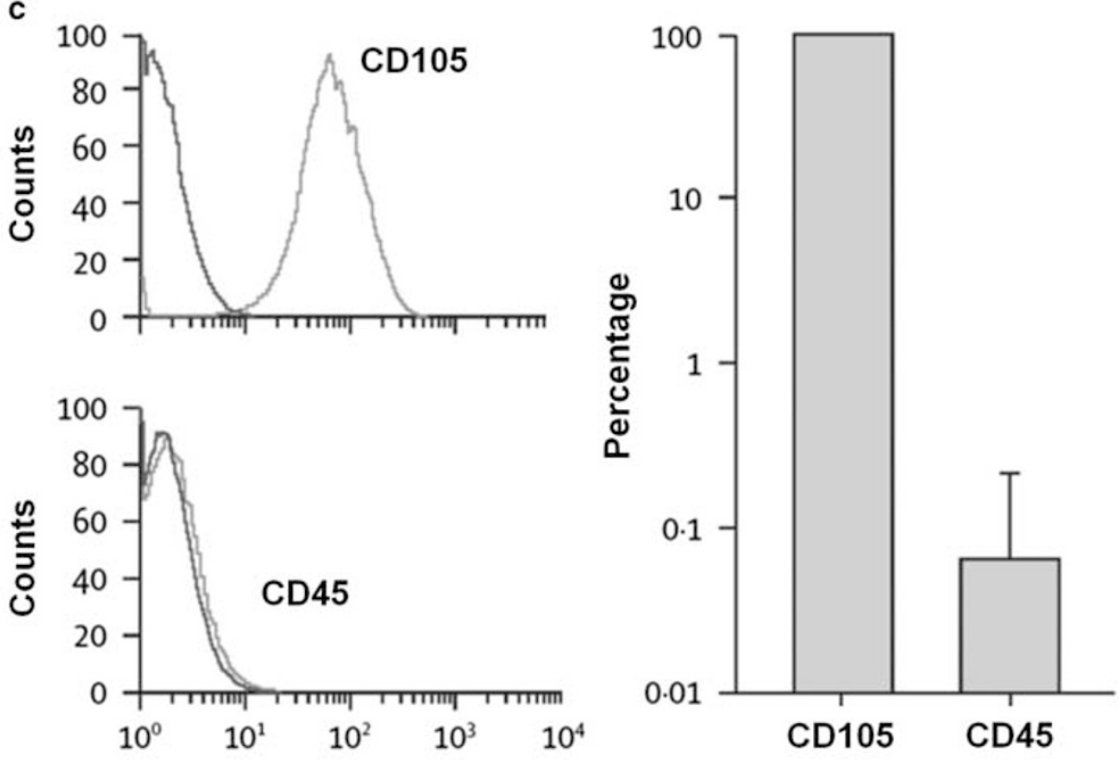

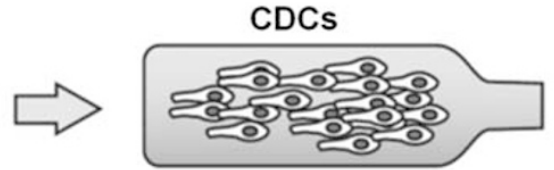

Cardiospheres

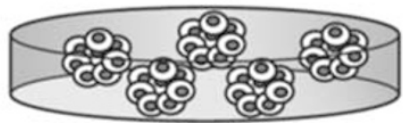

Figure 4 Preparation and characteristics of cardiosphere-derived cells (CDCs). (a) Preparation of CDCs. Biopsy samples were cut into small pieces of explants (A) that spontaneously expanded the cell population. These explants were cultured in a suspension to generate three-dimensional (3D) cardiospheres (B). Subsequently, the cardiospheres adhered to TCPS dishes and generated CDCs (C). (b) Histogram of the time required to obtain a prespecified dose of 12.5 million or 25 million cells. (c) Expression of CD105 and CD45 CDCs analyzed by flow cytometry. Most CDCs expressed CD105 (98\%), whereas less than $0.5 \%$ expressed CD $45 .{ }^{41}$ Copyright 2012. Adapted with permission from Elsevier Ltd.

Therefore, Gao et al. investigated the effect of intracoronary infusion of hWJ-MSCs in patients with AMI. In this trial, 116 patients with AMI were randomly assigned to receive hWJMSCs or a placebo in their infarct arteries at 5-7 days after PCI. ${ }^{48}$ The absolute increase in myocardial viability determined by positron emission computed tomography (PET) and perfusion within the infarcted region investigated by single-photon emission computed tomography (SPECT) showed significantly better outcomes in the patients infused with hWJ-MSCs than in the patients that received the placebo at 4 months after treatment. The increase in the LVEF of patients infused with hWJ-MSCs $(7.8 \%)$ was found to be significantly higher than that of patients in the placebo group (2.8\%) after 18 months (Figure 6a). Furthermore, decreases in end-diastolic volumes and LV end-systolic volumes of patients treated with hWJ-MSCs relative to those of patients in placebo group were observed after 18 months (Figure $6 \mathrm{~b}$ ). ${ }^{48}$ This study suggests that the intracoronary infusion of hWJ-MSCs is safe and presents another option in the treatment of patients with AMI. 
a
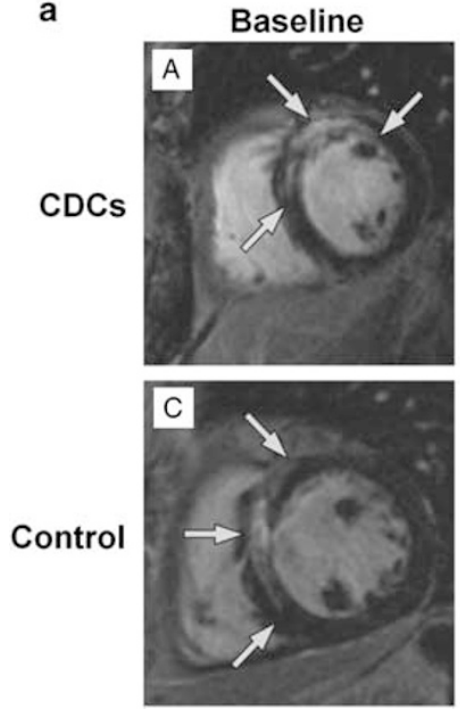

After 6 month
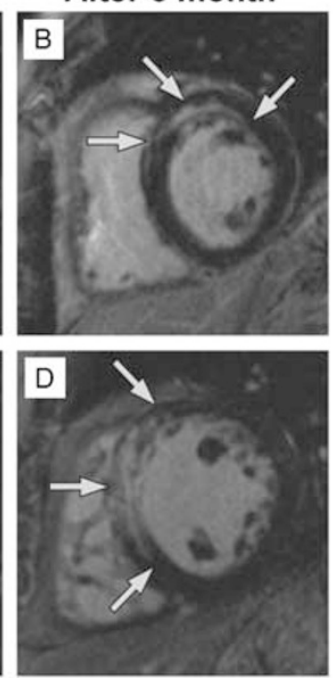

b

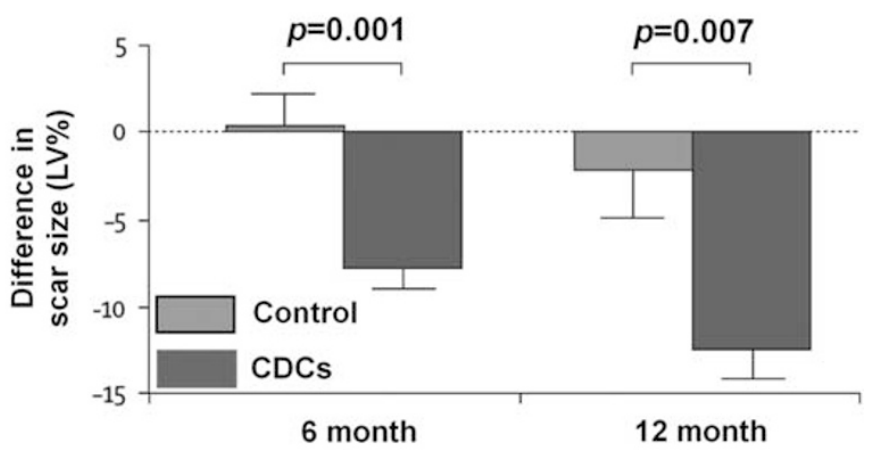

Figure 5 Representative magnetic resonance images (MRIs) of hearts of patients with myocardial infarction (MI) and changes in scar size (CADUCEUS clinical trial). (a) Short-axis MRI of the heart of a patient at baseline (82 days after MI, (A)) and 6 months after CDC transplantation (B). Short-axis MRI of the heart of a patient at baseline (77 days after myocardial infarction, (C)) and after 6 months (D) in a control. Infarct scar tissue (arrows) appear as sites of hyperintensity (white) and viable myocardium is indicated by dark spots. (b) Difference in scar size (LV\%) from baseline to 6 months or 12 months after treatment. ${ }^{41}$ Copyright 2012. Adapted with permission from Elsevier Ltd.

\section{a}

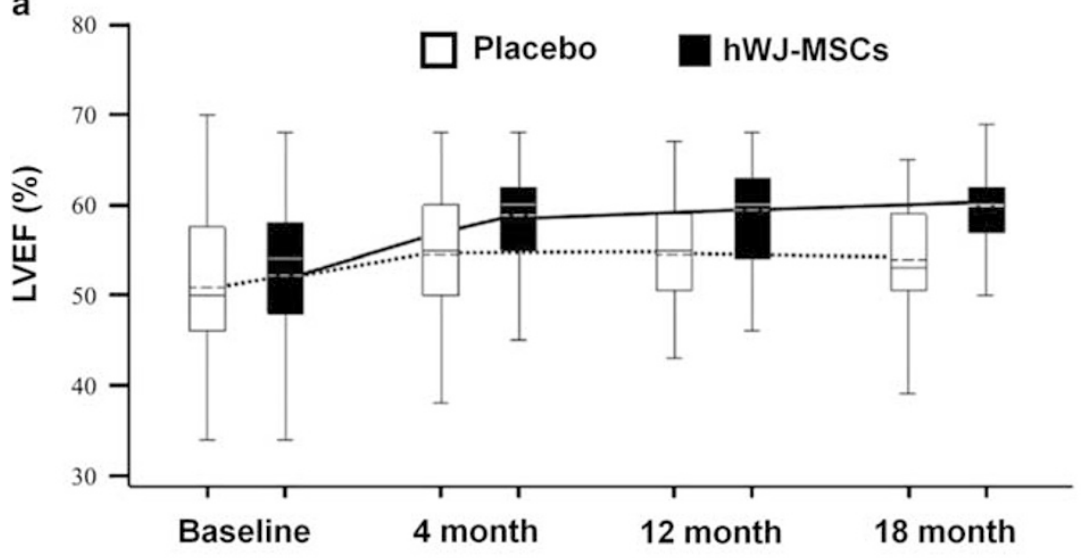

b

Placebo hWJ-MSCs Placebo hWJ-MSCs

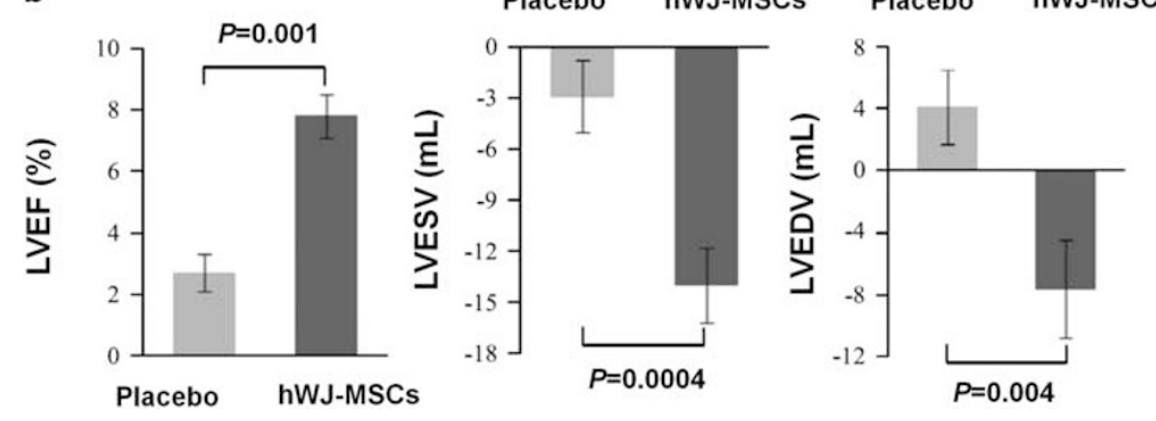

Figure 6 Intracoronary infusion of Wharton's jelly-derived mesenchymal stem cells in acute myocardial infarction. (a) Comparison of changes in global LVEF (left ventricular ejection fraction) between the placebo group and the hWJ-MSC (Wharton's jelly-derived MSC) treatment group evaluated by twodimensional echocardiography before infusion and after infusion at 4, 12, and 18 months. (b) Absolute changes in left ventricular end-diastolic volume (LVEDV), left ventricular end-systolic volume (LVESV), and LVEF between the placebo group and the WJMSC group at 18 months determined by echocardiograph. ${ }^{48}$ Adapted under a Creative Commons Attribution License. 


\section{Therapies Using Adipose-Derived Stromal Cells}

Adipose tissue contains multipotent adipose-derived stromal cells (ADSCs), representing an easily accessible and abundant cell source. ADSCs were reported to differentiate into cardiomyocytes and endothelial cells in vivo in an animal study, which indicates that ADSCs may be another promising source of cells to create new cardiomyocytes and blood vessels in patients with chronic ischemic heart disease. ${ }^{69}$ There are several clinical trials using freshly isolated human ADSCs (PRECISE clinical trial [NCT00426868] and APOLLO clinical trial [NCT00442806]) or cultured and expanded ADSCs (MyStromalCell clinical trial [NCT01449032]) to treat patients with AMI. However, to date, no results from these clinical trials have been reported.

The randomized, double-blinded, placebo-controlled trials of intracoronary infusions of several cell types, including (a) human bone marrow-derived MSCs, (b) human adiposederived stem cells, (c) hPSC-derived human cardiac progenitor cells, and (d) hPSC-derived cardiomyocytes to treat patients with AMI should be investigated more and compared with improve LV function in patients with AMI in the future.

\section{CONCLUSION}

Treatments using hPSCs are currently in clinical trials for the following conditions: diabetes, spinal cord injury, acute cardiac infarction disease, and macular degeneration disease. In this review, we discussed the bioengineering aspect of treatments using stem cells for patients with AMI. In current clinical trials using hESCs, the differentiated cells into progenitor cells (eg, cardiac progenitors) are commonly used, whereas in most of fundamental research, hESCs or hiPSCs are sophisticatedly induced to be differentiated into not progenitor cells, but mature stages of specific lineages of the cells. ${ }^{70-73}$ More efficient differentiation methods and/or sophisticated purification (isolation) methods should be developed for clinical usage of differentiated lineages of hESCs and hiPSCs. On the other hand, hMSCs, non-purified mononuclear cells from bone marrow or hMSCs not induced to differentiate into cardiac lineages, are typically used in the treatment of AMI, ${ }^{22-44,47,74}$ whereas most basic research has been applied investigating the differentiation of hMSCs into mature cardiomyocytes. ${ }^{75-79}$ Although purified hMSCs from bone marrow and cardiac progenitor cells have been used in clinical applications for patients with AMI, only a few trials have been reported to date using hPSCs (ie, hESCs). ${ }^{16,17}$ Therefore, there seems to have a gap between clinical usage of hPSCs or hMSCs and fundamental research on culture and differentiation methods for stem cells. The authors recommend that bioengineers attempt to decrease these gaps between fundamental research and clinical application of hMSCs and hESCs after consideration of this manuscript. The development of efficient and simple purification and/or differentiation methods to obtain specific lineages of cells from stem cells (hESCs, hiPSCs, hMSCs, or fetal stem cells) or tissue samples (bone marrow or adipose tissue) that maintain their biological function and activity, should be prioritized when differentiated cells from stem cells are clinically applied in the future. It will be important to develop cell sorting plates for the cultivation of cells on specific biomaterials for the selection of target cells, which we are going to differentiate or purify. ${ }^{80}$ Currently, in many instances, infused stem cells or stem cell-derived cells are left in the transplantation site in patients. The sophistication of methods for transplanting stem cell-derived cells or stem cells into patients should be increased with the use of injectable scaffolds or hydrogels for better survival rates of transplanted cells in patients over a long period of time. Developing these sophisticated delivery methods should be another task of bioengineers in this field.

Supplementary Information accompanies the paper on the Laboratory Investigation website (http://www.laboratoryinvestigation.org)

\section{ACKNOWLEDGMENTS}

This work was supported by Ministry of Science and Technology, Taiwan (grant no. MOST-104-2221-E-008-107-MY3 and MOST-105-2119-M-008-006). A Grant-in-Aid for Scientific Research (15K06591) from the Ministry of Education, Culture, Sports, Science, and Technology of Japan also supported this study. This work was also supported by the LandSeed Hospital project (NCU-

LSH-105-A-001). We acknowledge Deanship of Scientific Research, College of Science Research Centre, King Saud University, and Kingdom of Saudi Arabia.

\section{DISCLOSURE/CONFLICT OF INTEREST}

The authors declare no conflict of interest.

1. Kimbrel EA, Lanza R. Current status of pluripotent stem cells: moving the first therapies to the clinic. Nat Rev Drug Discov 2015;14:681-692.

2. Ramsden $C M$, Powner MB, Carr AJ, et al. Stem cells in retinal regeneration: past, present and future. Development 2013;140:2576-2585.

3. Pennington BO, Clegg DO. Pluripotent stem cell-based therapies in combination with substrate for the treatment of age-related macular degeneration. J Ocul Pharmacol Ther 2016;32:261-271.

4. Nazari H, Zhang L, Zhu D, et al. Stem cell based therapies for agerelated macular degeneration: the promises and the challenges. Prog Retin Eye Res 2015;48:1-39.

5. Carr AJ, Smart MJ, Ramsden CM, et al. Development of human embryonic stem cell therapies for age-related macular degeneration. Trends Neurosci 2013;36:385-395.

6. Malliaras K, Marban E. Cardiac cell therapy: where we've been, where we are, and where we should be headed. Br Med Bull 2011;98: 161-185.

7. Roger VL, Go AS, Lloyd-Jones DM, et al. Heart disease and stroke statistics-2012 update: a report from the American Heart Association. Circulation 2012;125:e2-e220.

8. Moss AJ, Zareba W, Hall WJ, et al. Prophylactic implantation of a defibrillator in patients with myocardial infarction and reduced ejection fraction. N Engl J Med 2002;346:877-883.

9. Higuchi A, Ling QD, Kumar SS, et al. Generation of pluripotent stem cells without the use of genetic material. Lab Invest 2015;95: 26-42.

10. Higuchi A, Ling QD, Kumar S, et al. Design of polymeric materials for culturing human pluripotent stem cells: progress toward feeder-free and xeno-free culturing. Prog Polym Sci 2014;39:1348-1374.

11. Higuchi A, Ling QD, Chang Y, et al. Physical cues of biomaterials guide stem cell differentiation fate. Chem Rev 2013;113:3297-3328.

12. Schwartz SD, Hubschman JP, Heilwell G, et al. Embryonic stem cell trials for macular degeneration: a preliminary report. Lancet 2012;379: 713-720.

13. Schwartz SD, Regillo CD, Lam BL, et al. Human embryonic stem cellderived retinal pigment epithelium in patients with age-related macular degeneration and Stargardt's macular dystrophy: follow-up of two open-label phase 1/2 studies. Lancet 2015;385:509-516. 
14. Kamao H, Mandai M, Okamoto $\mathrm{S}$, et al. Characterization of human induced pluripotent stem cell-derived retinal pigment epithelium cell sheets aiming for clinical application. Stem Cell Rep 2014;2:205-218.

15. Menasche P, Vanneaux V, Fabreguettes JR, et al. Towards a clinical use of human embryonic stem cell-derived cardiac progenitors: a translational experience. Eur Heart J 2015;36:743-750.

16. Menasche $P$, Vanneaux $V$, Hagege $A$, et al. Human embryonic stem cellderived cardiac progenitors for severe heart failure treatment: first clinical case report. Eur Heart J 2015;36:2011-2017.

17. Bellamy $\mathrm{V}$, Vanneaux $\mathrm{V}$, Bel $\mathrm{A}$, et al. Long-term functional benefits of human embryonic stem cell-derived cardiac progenitors embedded into a fibrin scaffold. J Heart Lung Transplant 2015;34:1198-1207.

18. Xiong Q, Hill KL, Li Q, et al. A fibrin patch-based enhanced delivery of human embryonic stem cell-derived vascular cell transplantation in a porcine model of postinfarction left ventricular remodeling. Stem Cells 2011;29:367-375.

19. Vallee JP, Hauwel M, Lepetit-Coiffe M, et al. Embryonic stem cell-based cardiopatches improve cardiac function in infarcted rats. Stem Cells Transl Med 2012;1:248-260.

20. Ye L, Zimmermann WH, Garry DJ, et al. Patching the heart: cardiac repair from within and outside. Circ Res 2013;113:922-932.

21. Stillman $A E$, Oudkerk $M$, Bluemke $D$, et al. Assessment of acute myocardial infarction: current status and recommendations from the North American society for Cardiovascular Imaging and the European Society of Cardiac Radiology. Int J Cardiovasc Imaging 2011;27:7-24.

22. Orlic D, Kajstura J, Chimenti $\mathrm{S}$, et al. Bone marrow cells regenerate infarcted myocardium. Nature 2001;410:701-705.

23. Lunde K, Solheim S, Aakhus S, et al. Autologous stem cell transplantation in acute myocardial infarction: The ASTAMI randomized controlled trial. Intracoronary transplantation of autologous mononuclear bone marrow cells, study design and safety aspects. Scand Cardiovasc J 2005;39:150-158.

24. Wollert KC, Meyer GP, Lotz J, et al. Intracoronary autologous bonemarrow cell transfer after myocardial infarction: the BOOST randomised controlled clinical trial. Lancet 2004;364:141-148.

25. Meyer GP, Wollert KC, Lotz J, et al. Intracoronary bone marrow cell transfer after myocardial infarction: eighteen months' follow-up data from the randomized, controlled BOOST (BOne marrOw transfer to enhance ST-elevation infarct regeneration) trial. Circulation 2006;113: 1287-1294.

26. Meyer GP, Wollert KC, Lotz J, et al. Intracoronary bone marrow cell transfer after myocardial infarction: 5-year follow-up from the randomized-controlled BOOST trial. Eur Heart J 2009;30:2978-2984.

27. Schachinger V, Erbs S, Elsasser A, et al. Intracoronary bone marrowderived progenitor cells in acute myocardial infarction. N Engl J Med 2006;355:1210-1221.

28. Schachinger V, Erbs S, Elsasser A, et al. Improved clinical outcome after intracoronary administration of bone-marrow-derived progenitor cells in acute myocardial infarction: final 1-year results of the REPAIRAMI trial. Eur Heart J 2006;27:2775-2783.

29. Erbs S, Linke A, Schachinger V, et al. Restoration of microvascular function in the infarct-related artery by intracoronary transplantation of bone marrow progenitor cells in patients with acute myocardial infarction: the Doppler Substudy of the Reinfusion of Enriched Progenitor Cells and Infarct Remodeling in Acute Myocardial Infarction (REPAIR-AMI) trial. Circulation 2007;116:366-374.

30. Dill T, Schachinger $V$, Rolf $A$, et al. Intracoronary administration of bone marrow-derived progenitor cells improves left ventricular function in patients at risk for adverse remodeling after acute ST-segment elevation myocardial infarction: results of the Reinfusion of Enriched Progenitor cells And Infarct Remodeling in Acute Myocardial Infarction study (REPAIR-AMI) cardiac magnetic resonance imaging substudy. Am Heart J 2009;157:541-547.

31. Assmus B, Rolf A, Erbs $\mathrm{S}$, et al. Clinical outcome 2 years after intracoronary administration of bone marrow-derived progenitor cells in acute myocardial infarction. Circ Heart Fail 2010;3:89-96.

32. Janssens S, Dubois C, Bogaert J, et al. Autologous bone marrowderived stem-cell transfer in patients with ST-segment elevation myocardial infarction: double-blind, randomised controlled trial. Lancet 2006;367:113-121.

33. Tendera M, Wojakowski W, Ruzyllo W, et al. Intracoronary infusion of bone marrow-derived selected CD34+CXCR4+ cells and non-selected mononuclear cells in patients with acute STEMI and reduced left ventricular ejection fraction: results of randomized, multicentre Myocardial Regeneration by Intracoronary Infusion of Selected Population of Stem Cells in Acute Myocardial Infarction (REGENT) Trial. Eur Heart J 2009;30:1313-1321.

34. Trachtenberg B, Velazquez DL, Williams AR, et al. Rationale and design of the transendocardial injection of autologous human cells (bone marrow or mesenchymal) in chronic ischemic left ventricular dysfunction and heart failure secondary to myocardial infarction (TAC-HFT) trial: a randomized, double-blind, placebo-controlled study of safety and efficacy. Am Heart J 2011;161:487-493.

35. Hare JM, Traverse JH, Henry TD, et al. A randomized, double-blind, placebo-controlled, dose-escalation study of intravenous adult human mesenchymal stem cells (prochymal) after acute myocardial infarction. J Am Coll Cardiol 2009;54:2277-2286.

36. Bolli R, Chugh AR, D'Amario D, et al. Cardiac stem cells in patients with ischaemic cardiomyopathy (SCIPIO): initial results of a randomised phase 1 trial. Lancet 2011;378:1847-1857.

37. Traverse $\mathrm{JH}$, Henry TD, Pepine CJ, et al. Effect of the use and timing of bone marrow mononuclear cell delivery on left ventricular function after acute myocardial infarction: the TIME randomized trial. JAMA 2012;308:2380-2389.

38. Traverse JH, Henry TD, Ellis SG, et al. Effect of intracoronary delivery of autologous bone marrow mononuclear cells 2 to 3 weeks following acute myocardial infarction on left ventricular function: the LateTIME randomized trial. JAMA 2011;306:2110-2119.

39. Hirsch A, Nijveldt R, van der Vleuten PA, et al. Intracoronary infusion of mononuclear cells from bone marrow or peripheral blood compared with standard therapy in patients after acute myocardial infarction treated by primary percutaneous coronary intervention: results of the randomized controlled HEBE trial. Eur Heart J 2011;32:1736-1747.

40. Roncalli J, Mouquet F, Piot C, et al. Intracoronary autologous mononucleated bone marrow cell infusion for acute myocardial infarction: results of the randomized multicenter BONAMI trial. Eur Heart J 2011;32:1748-1757.

41. Makkar RR, Smith RR, Cheng K, et al. Intracoronary cardiospherederived cells for heart regeneration after myocardial infarction (CADUCEUS): a prospective, randomised phase 1 trial. Lancet 2012;379: 895-904.

42. Bartunek J, Behfar A, Dolatabadi D, et al. Cardiopoietic stem cell therapy in heart failure: the C-CURE (Cardiopoietic stem Cell therapy in heart failURE) multicenter randomized trial with lineage-specified biologics. J Am Coll Cardiol 2013;61:2329-2338.

43. Wohrle J, von Scheidt F, Schauwecker $\mathrm{P}$, et al. Impact of cell number and microvascular obstruction in patients with bone-marrow derived cell therapy: final results from the randomized, double-blind, placebo controlled intracoronary Stem Cell therapy in patients with Acute Myocardial Infarction (SCAMI) trial. Clin Res Cardiol 2013;102:765-770.

44. Hu X, Huang X, Yang Q, et al. Safety and efficacy of intracoronary hypoxia-preconditioned bone marrow mononuclear cell administration for acute myocardial infarction patients: The CHINA-AMI randomized controlled trial. Int J Cardiol 2015;184:446-451.

45. Choudry F, Hamshere S, Saunders N, et al. A randomized double-blind control study of early intra-coronary autologous bone marrow cell infusion in acute myocardial infarction: the REGENERATE-AMI clinical trialdagger. Eur Heart J 2016;37:256-263.

46. Lunde K, Solheim S, Aakhus S, et al. Intracoronary injection of mononuclear bone marrow cells in acute myocardial infarction. N Eng J Med 2006;355:1199-1209.

47. Lee JW, Lee SH, Youn YJ, et al. A randomized, open-label, multicenter trial for the safety and efficacy of adult mesenchymal stem cells after acute myocardial infarction. J Korean Med Sci 2014;29:23-31.

48. Gao LR, Chen Y, Zhang NK, et al. Intracoronary infusion of Wharton's jelly-derived mesenchymal stem cells in acute myocardial infarction: double-blind, randomized controlled trial. BMC Med 2015;13:162.

49. Dimmeler S, Zeiher AM. Cell therapy of acute myocardial infarction: open questions. Cardiology 2009;113:155-160.

50. Schaefer A, Meyer GP, Fuchs M, et al. Impact of intracoronary bone marrow cell transfer on diastolic function in patients after acute myocardial infarction: results from the BOOST trial. Eur Heart J 2006;27: 929-935.

51. Zimmet H, Porapakkham P, Porapakkham P, et al. Short- and long-term outcomes of intracoronary and endogenously mobilized bone marrow stem cells in the treatment of ST-segment elevation myocardial 
infarction: a meta-analysis of randomized control trials. Eur J Heart Fail 2012;14:91-105.

52. Sussman MA, Murry CE. Bones of contention: marrow-derived cells in myocardial regeneration. J Mol Cell Cardiol 2008;44:950-953.

53. Liu B, Duan CY, Luo CF, et al. Effectiveness and safety of selected bone marrow stem cells on left ventricular function in patients with acute myocardial infarction: a meta-analysis of randomized controlled trials. Int J Cardiol 2014;177:764-770.

54. Engelmann MG, Theiss HD, Hennig-Theiss C, et al. Autologous bone marrow stem cell mobilization induced by granulocyte colonystimulating factor after subacute ST-segment elevation myocardial infarction undergoing late revascularization: final results from the G-CSFSTEMI (Granulocyte Colony-Stimulating Factor ST-Segment Elevation Myocardial Infarction) trial. J Am Coll Cardiol 2006;48:1712-1721.

55. Ripa RS, Jorgensen E, Wang $Y$, et al. Stem cell mobilization induced by subcutaneous granulocyte-colony stimulating factor to improve cardiac regeneration after acute ST-elevation myocardial infarction: result of the double-blind, randomized, placebo-controlled stem cells in myocardial infarction (STEMMI) trial. Circulation 2006;113: 1983-1992.

56. Zhang S, Sun A, Xu D, et al. Impact of timing on efficacy and safetyof intracoronary autologous bone marrow stem cells transplantation in acute myocardial infarction: a pooled subgroup analysis of randomized controlled trials. Clin Cardiol 2009;32:458-466.

57. Korf-Klingebiel M, Kempf T, Sauer T, et al. Bone marrow cells are a rich source of growth factors and cytokines: implications for cell therapy trials after myocardial infarction. Eur Heart J 2008;29:2851-2858.

58. de Jong $\mathrm{R}$, Houtgraaf $\mathrm{JH}$, Samiei $\mathrm{S}$, et al. Intracoronary stem cell infusion after acute myocardial infarction: a meta-analysis and update on clinical trials. Circ Cardiovasc Interv 2014;7:156-167.

59. Kucia M, Dawn B, Hunt G, et al. Cells expressing early cardiac markers reside in the bone marrow and are mobilized into the peripheral blood after myocardial infarction. Circ Res 2004;95:1191-1199.

60. Higuchi A, Wang CT, Ling QD, et al. A hybrid-membrane migration method to isolate high-purity adipose-derived stem cells from fat tissues. Sci Rep 2015;5:10217.

61. Chen DC, Chen LY, Ling QD, et al. Purification of human adiposederived stem cells from fat tissues using PLGA/silk screen hybrid membranes. Biomaterials 2014;35:4278-4287.

62. Bao L, Meng Q, Li Y, et al. C-Kit positive cardiac stem cells and bone marrow-derived mesenchymal stem cells synergistically enhance angiogenesis and improve cardiac function after myocardial infarction in a paracrine manner. J Card Fail 2017;23:403-415.

63. Hong KU, Guo Y, Li QH, et al. c-kit+ Cardiac stem cells alleviate post-myocardial infarction left ventricular dysfunction despite poor engraftment and negligible retention in the recipient heart. PLoS One 2014;9:e96725.

64. Wang HS, Hung SC, Peng ST, et al. Mesenchymal stem cells in the Wharton's jelly of the human umbilical cord. Stem Cells 2004;22: 1330-1337.

65. Troyer DL, Weiss ML. Wharton's jelly-derived cells are a primitive stromal cell population. Stem Cells 2008;26:591-599.
66. Gao LR, Zhang NK, Ding QA, et al. Common expression of stemness molecular markers and early cardiac transcription factors in human Wharton's jelly-derived mesenchymal stem cells and embryonic stem cells. Cell Transplant 2013;22:1883-1900.

67. Zhang W, Liu XC, Yang L, et al. Wharton's jelly-derived mesenchymal stem cells promote myocardial regeneration and cardiac repair after miniswine acute myocardial infarction. Coron Artery Dis 2013;24: 549-558.

68. Lopez Y, Lutjemeier B, Seshareddy K, et al. Wharton's jelly or bone marrow mesenchymal stromal cells improve cardiac function following myocardial infarction for more than 32 weeks in a rat model: a preliminary report. Curr Stem Cell Res Therapy 2013;8:46-59.

69. Qayyum AA, Haack-Sorensen M, Mathiasen AB, et al. Adipose-derived mesenchymal stromal cells for chronic myocardial ischemia (MyStromalCell Trial): study design. Regen Med 2012;7:421-428.

70. Francis MP, Breathwaite $E$, Bulysheva $A A$, et al. Human placenta hydrogel reduces scarring in a rat model of cardiac ischemia and enhances cardiomyocyte and stem cell cultures. Acta Biomater 2017;52:92-104.

71. Zhang $\mathrm{W}$, Kong $\mathrm{CW}$, Tong $\mathrm{MH}$, et al. Maturation of human embryonic stem cell-derived cardiomyocytes ( $\mathrm{hESC}-\mathrm{CMs}$ ) in 3D collagen matrix: effects of niche cell supplementation and mechanical stimulation. Acta Biomater 2017;49:204-217.

72. Hazeltine LB, Badur MG, Lian X, et al. Temporal impact of substrate mechanics on differentiation of human embryonic stem cells to cardiomyocytes. Acta Biomater 2014;10:604-612.

73. Higuchi A, Kumar SS, Ling QD, et al. Polymeric design of cell culture materials that guide the differentiation of human pluripotent stem cells. Prog Polym Sci 2017;65:83-126.

74. Qiang $Y$, Liang G, Yu L. Human amniotic mesenchymal stem cells alleviate lung injury induced by ischemia and reperfusion after cardiopulmonary bypass in dogs. Lab Invest 2016;96:537-546.

75. Mohanty S, Bose S, Jain KG, et al. TGFbeta1 contributes to cardiomyogenic-like differentiation of human bone marrow mesenchymal stem cells. Int J Cardiol 2013;163:93-99.

76. Shi $S$, Wu X, Wang $X$, et al. Differentiation of bone marrow mesenchymal stem cells to cardiomyocyte-like cells is regulated by the combined low dose treatment of transforming growth factorbeta1 and 5-azacytidine. Stem Cells Int 2016;2016:3816256.

77. Chen Y, Wang C, Huang Q, et al. Caveolin-1 plays an important role in the differentiation of bone marrow-derived mesenchymal stem cells into cardiomyocytes. Cardiology 2017;136:40-48.

78. Khajeniazi S, Solati M, Yazdani Y, et al. Synergistic induction of cardiomyocyte differentiation from human bone marrow mesenchymal stem cells by interleukin 1beta and 5-azacytidine. Biol Chem 2016;397: 1355-1364.

79. Yang L, Soonpaa MH, Adler ED, et al. Human cardiovascular progenitor cells develop from a KDR+ embryonic-stem-cell-derived population. Nature 2008;453:524-528.

80. Higuchi A, Kumar SS, Benelli G, et al. Stem cell therapies for reversing vision Los. Trends Biotechnol, http://dx.doi.org/10.1016/j.tibtech.2017. 06.016 . 